\title{
Sustainable development of smart cities: a systematic review of the literature
}

\author{
Evelin Priscila Trindade ${ }^{1}$, Marcus Phoebe Farias Hinnig ${ }^{1}$, Eduardo Moreira da Costa', Jamile Sabatini Marques ${ }^{1}$, \\ Rogério Cid Bastos ${ }^{1}$ and Tan Yigitcanlar ${ }^{2^{*}}$ (D)
}

\author{
* Correspondence: \\ tan@worldcapitalinstitute.org \\ ${ }^{2}$ World Capital Institute, E. Garza \\ Sada 2501 Sur, P.C. 64849, \\ Monterrey, N.L, Mexico \\ Full list of author information is \\ available at the end of the article
}

\begin{abstract}
This paper aims to analyse scientific studies focusing on both environmental sustainability and smart city concepts to understand the relationship between these two. In order to do so the study identifies information about researchers, models, frameworks and tools focused on the chosen themes. This research uses a qualitative methodology, through a systematic review of the literature, which examines the terms, 'smart city' and 'sustainability', aimed at sustainable development of smart cities. For this, three databases were used: Scopus, Science Direct, and Emerald Insight. This paper provides detailed information on the most recent scientific articles focusing on smart cities and sustainability issues. The paper can serve as a basis for researchers seeking background information for further investigations. The findings provide invaluable insights for scholars researching on the subject, and public managers considering applying those into practice in their cities.
\end{abstract}

Keywords: Smart city, Smart community, Sustainable city, Environmental sustainability, Sustainable urban development

\section{Introduction}

Since the mid-twentieth century, numerous environmental, social and economic crises on a global scale have significantly affected our societies (Yigitcanlar and Lee 2014). Especially during the last two decades, metropolitan areas around the world have been engaged in initiatives to improve urban infrastructure and services, aiming at a better environment, social and economic conditions, improving the attractiveness and competitiveness of cities (Lee et al. 2008; Jong et al. 2015). These efforts brought up the concept of intelligent cities (Komninos 2002) that is the predecessor of smart cities (Yigitcanlar 2015). According to Deakin and Al Waer (2012) and Townsend (2013), smart cities arise due to the intelligent use of digital information, for example in the areas such as human health, mobility, energy use, education, knowledge transfer and urban governance.

Sustainability and sustainable urban development concepts generates awareness of the production and use of resources required for residential, industrial, transportation, commercial or recreational processes (Yigitcanlar et al. 2007; Pietrosemoli and Monroy 2013; Goonetilleke et al. 2014; Yigitcanlar and Kamruzzaman 2014, 2015). Sustainable urban development corroborates, aiming at environmental awareness in the use of natural resources in smart cities (Dizdaroglu and Yigitcanlar 2014; Yigitcanlar and

(c) The Author(s). 2017 Open Access This article is distributed under the terms of the Creative Commons Attribution 4.0 International License (http://creativecommons.org/licenses/by/4.0/), which permits unrestricted use, distribution, and reproduction in any medium, provided you give appropriate credit to the original author(s) and the source, provide a link to the Creative Commons license, and indicate if changes were made. 
Teriman 2015; Komninos 2016). Yigitcanlar and Dizdaroglu (2015) focus on the concept of ecological cities in their research. This concept has been developed and promoted since 1970 as part of the sustainable development agenda.

This paper provides a systematic review of the literature selected from three databases: Emerald Insight, Science Direct, and Scopus. The keywords used for the selection include: 'smart city' and 'sustainability' terms. The paper seeks to address the following overall research questions: What is the relationship between the concepts of sustainable urban development and smart cities? In order to explore this issue we also looked into the following secondary research questions: (a) Which articles do involve both the terms smart city and environmental sustainability? (b) What information are provided in these articles? (c) What kind of models, frameworks or tools do these articles present?

\section{Sustainable urban development and smart city}

The concept of smart city is relatively new and can be seen as a successor of information city, digital city and sustainable city (Yigitcanlar 2006). However it has been used frequently, especially after 2013, when it exceeded a frequency of citations of other terms including sustainable city (Yigitcanlar 2006). However it has been used frequently, especially after 2013, when it exceeded a frequency of citations of other terms including sustainable city (Jong et al. 2015; Yigitcanlar 2016). Despite the discussion about its concept in recent years, there is a lack of consensus on what a smart city is (Angelidou 2015; Hortz 2016). Although a number of authors have the difficulty of conceptualisation, these definitions are not contradictory but partially overlapping (Scheel and Rivera 2013; Cocchia 2014). In general, however, it is understood that smart cities make use of information and communication technology (ICT) extensively to help cities to build their competitive advantages (Yigitcanlar and Baum 2008; Caragliu et al. 2011), or that it is a conceptual model where urban development is achieved through the use of human, collective and technological capital (Angelidou 2014). The term smart city is, therefore, an umbrella concept that contains a number of subthemes such as smart urbanism, smart economy, sustainable and smart environment, smart technology, smart energy, smart mobility, smart health, and so on (Gudes et al. 2010; Cocchia 2014; Lara et al. 2016).

In their literature review, Caragliu et al. (2011) conceptualise smart city with the following main characteristics: (a) An enhanced administrative and economic efficiency that enables the development of culture and society by utilising networked infrastructures; (b) An underlying emphasis on business oriented urban development; (c) A strong focus on the goal of realising the social inclusion of different kinds of urban residents in public services; (d) An emphasis on the significant role of high-tech and creative industries in long-term growth; (e) A perspective to pay close attention to the function of social and relational capital in city development, and; (f) A vision to take social and environmental sustainability as an important aspect of smart city development. Some authors also point to the necessary ingredients for the composition of a smart city, such as: smart economy, smart mobility, smart environment, smart people, smart living and smart governance (Lazaroiu and Roscia 2012; Lee et al. 2014; Jong et al. 2015). Additionally, the concept of smart city goes beyond the definitions of information cities, digital cities, and intelligent cities, because it contextualises technology to be used in favour of systems and services for people (Jong et al. 2015). 
The evaluation of a smart city, as discussed by Marsal-Llacuna et al. (2015) should consider past experiences of environmentally friendly and liveable cities, encompassing sustainability and quality of life, in addition, of course, the composition of technological factors. Lazaroiu and Roscia (2012) state that it should represent a technological community, interconnected, sustainable, comfortable, attractive, and secure. In order to understand how it works in practice, smart cities make use of city data for traffic management, energy consumption statistics, security, and optimising the operation of municipal services (Harrison et al. 2010). This new reality is encouraging the increase of new suppliers to the smart city market niche, using technological resources for the management of urban services (Carvalho and Campos 2013; Angelidou 2015).

Schaffers et al. (2011), later on emphasised by Kramers et al. (2014), point out that to have a smart city is necessary: (a) Create a rich environment of broadband networks that support digital applications, and; (b) Initiate large-scale participatory innovation processes for the creation of applications. Some cities that have appropriated the concept of smart cities have applied themselves to enjoy their benefits so that the needs of the city are met. Barcelona defines smart city as a high-tech intensive and advanced city that connects people, information and city elements using new technologies in order to create sustainable greener city, competitive and innovative commerce and an increased life quality, while the city of Amsterdam addresses the issue as an innovative technology and is willing to change people's energy-related behaviour to tackle climate challenges (Lee et al. 2014). In the case of Doha, smart city practice is more of an interaction of urban technologies and knowledge economy activities (Conventz et al. 2015); whereas in the case of Brisbane, the practice is to integrate smart technologies into good urban and space design practices (Pancholi et al. 2015).

Nam and Pardo (2011) divide smart city into three dimensions: (a) Technology (hardware and software infrastructures); (b) Population (creativity, diversity and education) and; (c) Institutions (governance and policy). In view of this, investments in technology, population and institutions aiming at the concept of smart city generate sustainable development and quality of life, promoting responsible management of natural resources and allowing institutions to contribute with innovation and better services for citizens, strengthening the debates and political participation (Caragliu et al. 2011).

When studying cities, to better understand the term sustainability, one must take into account the meaning of sustainable urban development (Dizdaroglu and Yigitcanlar 2016). This, in turn, can be seen as a process of change in which resource exploitation, investment direction, technological development and institutional change are consistent with present and future needs (WCED 1987). The term sustainable city as a concept became popular in the 1990s (Roy 2009) denoting the relationship between economic, social and environmental sustainability aspects from a combination of indicators of each of these components (Ahvenniemi et al. 2017). Although the current vision is to address these three issues to talk about sustainable cities, certain authors focus on one of only three. This is the case of Meadows (1999), who propose the inclusion of indicators such as pollution, waste generation and consumption of water and energy, unlike Rode and Burdett (2011), who direct efforts towards an interpretation More socioeconomic, such as social equity and a greener environment (Jong et al. 2015).

Considering all these aspects, Hiremath et al. (2013) define sustainable urban development as achieving a balance between the development of the urban areas and 
protection of the environment with an eye to equity in income, employment, shelter, basic services, social infrastructure and transportation in the urban areas. The spread of interest in smart cities and adjacent concepts is linked to a number of factors, including: most of the world's population living in cities, climate change, scarcity of natural resources, globalisation, and increased competition. With this, cities need to offer improved and customisable services for people (Angelidou 2015). According to Dhingra and Chattopadhyay (2016), a smart and sustainable city has goals to be achieved in an adaptable, reliable, scalable, accessible and resilient way, such as:

- Improve quality of life of its citizens;

- Ensure economic growth with better employment opportunities;

- Improve well-being of its citizens by ensuring access to social and community services;

- Establish an environmentally responsible and sustainable approach to development;

- Ensure efficient service delivery of basic services and infrastructure such as public transportation, water supply and drainage, telecommunication and other utilities;

- Ability to address climate change and environmental issues, and;

- Provide an effective regulatory and local governance mechanism ensuring equitable policies.

It is observed that, when it comes to the environmental issues of smart cities, the discussion is more political in nature, considering international resolutions and innovative solutions to combat complex urban challenges. According to the same author, there are four attributes of the smart and sustainable cities: (a) Sustainability; (b) Quality of life; (c) Urban aspects, and; (d) Intelligence. These are analysed under four main themes: (a) Society; (b) Economy; (c) Environment, and; (d) Governance (Carrillo et al. 2014; Kondepudi 2014). These themes are also presented by Yigitcanlar and Velibeyoglu (2008) and Yigitcanlar and Lönnqvist (2013) on their works on knowledge-based urban development, which is another concept that relates to the development of smart cities. A similar concept, smart-eco city, proposes that the city should be ecologically healthy, using advanced technologies and having economically productive and environmentally efficient industries, have a responsible and harmonious systematic culture, a physically aesthetic and functionally living landscape (Yigitcanlar and Lee 2014).

\section{Methodology}

The literature review is the basis for scientific writing. It is in the review that the researcher becomes familiar with the texts, identifies the eminent authors who have been writing on the topic (Ferenhof and Fernandes 2016). We have adopted a systematic analysis approach (Jesson et al. 2011) for the literature review. The systematic review searched for articles in three major databases: Emerald Insight, Science Direct, and Scopus. The search terms used were 'smart city' and 'sustainability'. EndNote software was used to assist in data compilation. As a result of the search, we obtain:

- 19 documents from the Scopus database;

- 49 documents from the Emerald database, and;

- 629 documents from the Science Direct database.

After verifying documents in duplicate, we got 630 articles. Of these, 353 were fully available on electronic format. Next, we evaluated the titles and key words to choose which documents dealt with the two terms 'smart city' and 'sustainability', and we 
Table 1 Reviewed literature

\begin{tabular}{lll}
\hline No & Literature & Aim \\
\hline 1 & Yigitcanlar, T., \& Lee, S. H. (2014). Korean ubiquitous- & The paper aims to put the premise of u-eco-city \\
eco-city: A smart-sustainable urban form or a & into a test and address whether u-eco-city is a \\
branding hoax?. Technological Forecasting and & $\begin{array}{l}\text { dazzling smart and sustainable urban form that } \\
\text { Social Change, 89, 100-114. }\end{array}$ & $\begin{array}{l}\text { constitutes an ideal twenty-first century city model } \\
\text { or just a branding hoax. }\end{array}$
\end{tabular}

2 Kramers, A., Höjer, M., Lövehagen, N., \& Wangel, J. (2014). Smart sustainable cities-Exploring ICT solutions for reduced energy use in cities. Environmental Modelling \& Software, 56, 52-62.

3 Götz, G., \& Schäffler, A. (2015). Conundrums in implementing a green economy in the Gauteng City-Region. Current Opinion in Environmental Sustainability, 13, 79-87.

4 Lazaroiu, G. C., \& Roscia, M. (2012). Definition methodology for the smart cities model. Energy, 47(1), 326-332

5 Lee, J. H., Hancock, M. G., \& Hu, M. C. (2014). Towards an effective framework for building smart cities: Lessons from Seoul and San Francisco. Technological Forecasting and Social Change, 89, 80-99.

This paper explores the opportunities of using ICT as an enabling technology to reduce energy use in our cities.

This paper analyses how these green economy strategies have faced conundrums that narrow the thinking on future growth paths, in turn threatening to reproduce a profoundly unsustainable regional economy.

This paper proposes a model for computing the smart city indices. However, the chosen indicators are not homogeneous, and contain high amount of information.

This paper develops a conceptual framework to examine and analyse two leading cases from the US and Asia. Through the lens of this new framework the paper identifies heterogeneous and heterogeneous characteristics in the process of planning and developing a smart city.

6 Marsal-Llacuna, M. L., Colomer-Llinàs, J., \& MeléndezFrigola, J. (2015). Lessons in urban monitoring taken from sustainable and livable cities to better address the Smart Cities initiative. Technological Forecasting and Social Change, 90, 611-622.

7 Joss, S. (2015). Eco-cities and Sustainable Urbanism. In International Encyclopedia of the Social \& Behavioral Sciences, pp. 829-837.

8 Bayulken, B., \& Huisingh, D. (2015). Are lessons from eco-towns helping planners make more effective progress in transforming cities into sustainable urban systems: a literature review (part 2 of 2). Journal of Cleaner Production, 109, 152-165.

$9 \mathrm{Hu}, \mathrm{M}$. C., Wu, C. Y., \& Shih, T. (2015). Creating a new socio-technical regime in China: Evidence from the Sino-Singapore Tianjin Eco-City. Futures, 70, 1-12.

10 Marsal-Llacuna, M. L., \& Segal, M. E. (2016). The Intelligenter Method (I) for making "smarter" city projects and plans. Cities, 55, 127-138.

11 Jong, M., Joss, S., Schraven, D., Zhan, C., \& Weijnen, M. (2015). Sustainable-smart-resilient-low carboneco-knowledge cities; making sense of a multitude of concepts promoting sustainable urbanization. Journal of Cleaner Production, 109, 25-38.

12 Ahvenniemi, H., Huovila, A., Pinto-Seppä, I., \& Airaksinen, M. (2017). What are the differences between sustainable and smart cities?. Cities, 60 , 234-245.

This paper puts forward new ideas for monitoring the smart cities initiative in a better way.

This paper focuses on the eco-city and related concepts and the practices of sustainable urbanism that have since the early 2000s gained growing international popularity and entered mainstream policy as a consequence of the forceful combination of global climate change concerns and a rapidly urbanizing world population.

This paper summarises and systematises the insights that have been obtained from eco-town based urban developments implemented in the North-western Europe with particular emphasis given into the examples from the Netherlands, Sweden and Germany.

This paper reveals that an expansion of the scale of urbanisation and its transformation into the focal point of the hub-and-spoke eco-city model will enable China to advance as an international pioneer, by the creation of a new socio-technical regime dependent on green and ecologically sustainable systems.

This paper proposes a first-of-its-kind method for the design of truly smart city projects and the elaboration of smarter urban planning. The Intelligenter Method is based on the innovative idea of collaborations discovery in urban systems.

This paper aims to investigate, through a comprehensive bibliometric analysis, the 12 most common city categories/typologies.

The paper analyses 16 sets of city assessment frameworks (eight smart city and eight urban sustainability assessment frameworks) comprising 958 indicators altogether by dividing the indicators under three impact categories and 12 sectors. 
Table 1 Reviewed literature (Continued) 13 Zhou, N., He, G., Williams, C., \& Fridley, D. (2015).
Elite cities: a low-carbon eco-city evaluation tool for
China. Ecological Indicators, 48, 448-456.

14 Tsolakis, N., \& Anthopoulos, L. (2015). Eco-cities: An integrated system dynamics framework and a concise research taxonomy. Sustainable Cities and Society, 17, 1-14.

15 Dhingra, M., \& Chattopadhyay, S. (2016). Advancing smartness of traditional settlements-case analysis of Indian and Arab old cities. International Journal of Sustainable Built Environment, 5(2), 549-563.

16 Fu, Y., \& Zhang, X. (2017). Trajectory of urban sustainability concepts: A 35-year bibliometric analysis. Cities, 60, 113-123.

17 Angelidou, M. (2015). Smart cities: A conjuncture of four forces. Cities, 47, 95-106.

18 Yigitcanlar, T., (2015). Smart cities: an effective urban development and management model? Australian Planner, 52(1), 27-34.

19 Lara, A., Costa, E., Furlani, T., \& Yigitcanlar, T., (2016). Smartness that matters: comprehensive and humancentred characterisation of smart cities. Journal of Open Innovation, 2(8), 1-13

20 Cohen, B., \& Amorós, J. E. (2014). Municipal demandside policy tools and the strategic management of technology life cycles. Technovation, 34(12), 797806.

21 Edvardsson, l., Yigitcanlar, T., \& Pancholi, S., (2016). Knowledge cities research and practice under the microscope: a review of the literature. Knowledge Management Research and Practice, 14(4), 537-564.

22 Tan, S., Yang, J., Yan, J., Lee, C., Hashim, H., \& Chen, B. (2017). A holistic low carbon city indicator framework for sustainable development. Applied Energy, 185, 1919-1930.

23 Neirotti, P., De Marco, A., Cagliano, A. C., Mangano, G., \& Scorrano, F. (2014). Current trends in Smart City initiatives: Some stylised facts. Cities, 38, 25-36.
This paper through its Elite cities framework

measures progress on 33 key indicators selected to represent priority issues within eight primary categories. An excel-based tool was developed to package the key indicators, indicator benchmarks, explanation of indicators, point calculation functions and transparency-oriented data recording instructions.

This paper addresses the problem of the eco-city paradigm assessment with a multi-method approach. It grounds three research questions with focus to eco-cities and applies alternative methodologies in an attempt to answer them.

The paper aims to investigate the concept of smart sustainable cities in traditionally planned and organically grown settlements. Smart Cities Mission is an ambitious project of Government of India targeting 100 cities for improving their urban quality of life.

This paper conducts a descriptive summary, a clustering analysis, and multidimensional scaling of major city concepts, by establishing a co-word matrix of high-frequency keywords occurring in the Science Citations Index and Social Science Citations Index databases.

This paper aims to identify the forces shaping the smart city conception and, by doing so, begins replacing the currently abstract image of what it means to be a smart city.

This paper aims to firstly, investigate the role of smart urban technologies in the progress of smart city formation, and thus providing conceptual clarity on smart cities, and; secondly, undertake a critical review of application attempts of the smart city model by looking into emerging practices of ubiquitous eco-cities as exemplar smart city initiatives from Korea.

This paper aims to undertake a comprehensive review of how smart cities are perceived in the literature and in the light of the findings propose a clearer definition with strong smart community focus.

This paper develops a conceptual framework that helps to understand how local governments might develop demand-side policy tools that stimulate the development and diffusion of sustainable-driven innovations that enhance local economic development.

This paper aims to scrutinise and provide a clear understanding on the evolution of knowledge city research and practice

This paper develops an indicator framework for the evaluation of low-carbon city from the perspectives of economic, energy pattern, social and living, carbon and environment, urban mobility, solid waste, and water.

This paper provides policy makers and city managers with useful guidelines to define and drive their smart city strategy and planning actions towards the most appropriate domains of implementation. 
Table 1 Reviewed literature (Continued)

\begin{tabular}{|c|c|c|}
\hline 24 & $\begin{array}{l}\text { Andrade, J. B. S. O., Ribeiro, J. M. P., Fernandez, F., } \\
\text { Bailey, C., Barbosa, S. B., \& da Silva Neiva, S. (2016). } \\
\text { The adoption of strategies for sustainable cities: A } \\
\text { comparative study between Newcastle and } \\
\text { Florianópolis focused on urban mobility. Journal of } \\
\text { Cleaner Production, 113, 681-694. }\end{array}$ & $\begin{array}{l}\text { This paper aims to analyse the differences between } \\
\text { public transportation in Newcastle upon Tyne, the } \\
\text { city considered the most sustainable in the UK, and } \\
\text { Florianopolis, a city with great potential for } \\
\text { sustainable policies located in Southern Brazil. }\end{array}$ \\
\hline 25 & $\begin{array}{l}\text { Hu, M. C., Wadin, J. L., Lo, H. C., \& Huang, J. Y. (2016). } \\
\text { Transformation toward an eco-city: lessons from } \\
\text { three Asian cities. Journal of Cleaner Production, } \\
\text { 123, 77-87. }\end{array}$ & $\begin{array}{l}\text { This paper elucidates the effects of different national } \\
\text { approaches to eco-city development and their } \\
\text { antecedents of the build comparing three Asian } \\
\text { cities. }\end{array}$ \\
\hline
\end{tabular}

selected 97 documents to be read. After reading the abstracts, we have 47 documents to read in full. After the reading these articles, considering which of them provided information about frameworks, models or tools adopted in smart cities in line with green sustainability, 25 documents were selected for the final analysis.

\section{Results}

This section discusses the results of selected 25 journal articles. The discussion includes similarities in the research, differences and bibliometric information of the research, such as main authors, keywords, journals in which the researches are published in, time scale, models, frameworks or tools. Table 1 lists the reviewed articles selected and their aims.

\section{Similarities and differences between reviewed literature}

Out of 25 articles reviewed, 11 of them contained information about models, frameworks and tools. Articles 7, 8, 17, 18 and 20 (see Table 1) provide information and discussions on concepts such as eco-city, sustainable urbanism, eco-towns, and smart city/smart cities. Another five of them, those with the numbers of 11, 12, 16, 19 and 21 present results of bibliometric analysis and/or systematic review. Three of them, articles 3, 15 and 18, present analyses of solutions in green economy and smart cities, article number 6 uses mathematical models to build statistics to monitor smart cities, and article 23 provide detailed guidelines for cities.

\section{Models, frameworks and tools}

A total of 11 articles presented research on models, frameworks or tools developed with smart cities and green sustainability in mind. None of the articles presented the same model, framework or tool. Table 2 briefly presents occurrences and a summary of each article.

It is important to point out that five of the models, frameworks and tools of 11 in total use ICT. These are:

- Korea city model, u-eco-city:

○ Analytical framework;

- Model for computing smart city indices;

$\circ$ Intelligenter method, and;

○ Holistic system dynamics methodological framework.

Six of them come up with hints of indicators or categories that can be used in smart cities. 
Table 2 Models, frameworks and tools

Literature
Yigitcanlar, T., \& Lee, S. H. (2014). Korean
ubiquitous-eco-city: A smart-sustainable
urban form or a branding hoax?.
Technological Forecasting and Social
Change, 89, 100-114.
Kramers, A., Höjer, M., Lövehagen, N., \&
Wangel, J. (2014). Smart sustainable cities-
Exploring ICT solutions for reduced energy
use in cities. Environmental Modelling \&
Software, 56, 52-62.
Lazaroiu, G. C., \& Roscia, M. (2012).
Definition methodology for the smart cities
model. Energy, 47(1), 326-332.
model. Energy, 47(1), 326-332.

Lee, J. H., Hancock, M. G., \& Hu, M. C. (2014). Towards an effective framework for building smart cities: Lessons from Seoul and San Francisco. Technological

Forecasting and Social Change, 89, 80-99.

Hu, M. C., Wu, C. Y., \& Shih, T. (2015). Creating a new socio-technical regime in China: Evidence from the Sino-Singapore Tianjin Eco-City. Futures, 70, 1-12.

Marsal-Llacuna, M. L., \& Segal, M. E. (2016). The Intelligenter Method (I) for making "smarter" city projects and plans. Cities, 55, 127-138.

Zhou, N., He, G., Williams, C., \& Fridley, D. (2015). Elite cities: a low-carbon eco-city evaluation tool for China. Ecological Indicators, 48, 448-456.

Tsolakis, N., \& Anthopoulos, L. (2015). Ecocities: An integrated system dynamics framework and a concise research taxonomy. Sustainable Cities and Society, $17,1-14$.

Cohen, B., \& Amorós, J. E. (2014). Municipal Conceptual demand-side policy tools and the strategic framework management of technology life cycles. Technovation, 34(12), 797-806.

Tan, S., Yang, J., Yan, J., Lee, C., Hashim, H., \& Chen, B. (2017). A holistic low carbon city indicator framework for sustainable development. Applied Energy, 185, 19191930.

Model for

Conceptual framework dynamics

$\begin{array}{ll}\text { Model } & \text { Summary } \\ \text { Korea city model, u- } & \text { U-eco-city is basically an ICT and eco- } \\ \text { eco-city } & \text { technology. The principal premise of a u- } \\ & \text { eco-city is to provide a high quality of life } \\ & \text { and place to residents, workers and visitors } \\ & \text { with low-to-no negative impacts on the } \\ & \text { natural environment with support from the } \\ & \text { state-of-the-art technologies in their } \\ & \text { planning, development and management. }\end{array}$

Analytical framework The analytical framework is intended to be of use to researches, city and regional authorities and ICT companies interested in acquiring a better understanding of how ICT investments could contribute to reduce energy use in cities. computing the smart city indices

The model uses a procedure based on fuzzy logic for indices. It could help in policy making process as starting point of discussion between stakeholders, as well as citizens in final decision of adoption measures and best evaluated options.

This research study generates taxonomies of 6 key conceptual dimensions and 17 sub-dimensions of smart city practices.

Eco-city model

This model comprises a cluster with one or two cities playing the central hub role, surrounded by several neighbouring city spokes, closely linked to the hub by means of connected transportation, state grid networks, and economic ties.

Intelligenter method The method is based on the innovative idea of collaborations discovery in urban systems. It shows that what makes an urban project or a plan smart is not its sophisticated architecture or complex master planning in a technological environment.

Elite cities tool The tool measures progress on 33 key indicators selected to represent priority issues within eight primary categories. It could be a useful and effective tool for local city government in defining the broad outlines of a low-carbon eco-city and assessing the progress of cities efforts towards this goal.

Holistic system methodological framework

The framework proposed, as a means to assist decision-makers, local governments and managers designing and adopting effective policies for monitoring and assessing the sustainable performance of eco-cities.

This research has sought to develop a grounded theoretical model for the integration of innovation policy and diffusion of innovation theory.

Indicator framework The low carbon city indicator framework analyses the low-carbon development progress of cities on 20 quantitative indicators across seven categories, covering city economic development, energy pattern, social and living, carbon and environmental, urban mobility, waste, and water. 
Table 2 Models, frameworks and tools (Continued)

\begin{tabular}{|c|c|c|}
\hline $\begin{array}{l}\text { Hu, M. C., Wadin, J. L., Lo, H. C., \& Huang, J. } \\
\text { Y. (2016). Transformation toward an eco- } \\
\text { city: lessons from three Asian cities. Journal } \\
\text { of Cleaner Production, 123, 77-87. }\end{array}$ & 3Es framework & $\begin{array}{l}\text { The major concerns of our time reveal that } \\
\text { a framework for assessing the sustainability } \\
\text { performance of an eco-city requires the } \\
\text { systematic integration of various aspects of } \\
\text { sustainability. Therefore, this paper } \\
\text { proposes a 3Es Framework (i.e., efficiency, } \\
\text { economy, and effectiveness). }\end{array}$ \\
\hline
\end{tabular}

- Model for computing smart city indices:

○ Conceptual framework;

○ Eco-city model;

- Elite cities tool;

○ Framework for the evaluation of low-carbon city, and;

○ 3Es framework (efficiency, economy, and effectiveness).

The model for computing smart city indices is the only one that uses both ICT and the indexes for smart cities.

\section{Authors and research locality}

Reviewed papers involved a total of 70 authors, with only three of them appearing in at least two papers. These two authors are: Mei-Chih $\mathrm{Hu}$ (China), Maria-Lluïsa Marsal-Llacuna (Spain), and Tan Yigitcanlar (Australia). The total number of country of origin of the authors was 18 countries. Table 3 lists the names of countries that were repeated more than once.

\section{Keywords}

Figure 1 below shows a cloud of tags with the keywords quoted in the selected articles.

\section{Journals}

Reviewed 25 articles were published in 15 journals. Table 4 displays the journals that had more than two articles published.

\section{Year of publication}

We analysed the information of the reviewed articles and verified that the publication year of the articles. The articles were published between 2012 and 2017 (the analysis conducted in February 2017), and in the year 2015 there were the largest number of publications on the subject, a total of 10 articles. Looking at the publication years of the documents, we have identified that the 'smart city and sustainability' topic has

Table 3 List of country of origin of authors

\begin{tabular}{lr}
\hline Country & Author \\
\hline China & 6 \\
USA & 3 \\
Australia & 3 \\
Korea & 2 \\
Greece & 2 \\
Spain & 2 \\
\hline
\end{tabular}




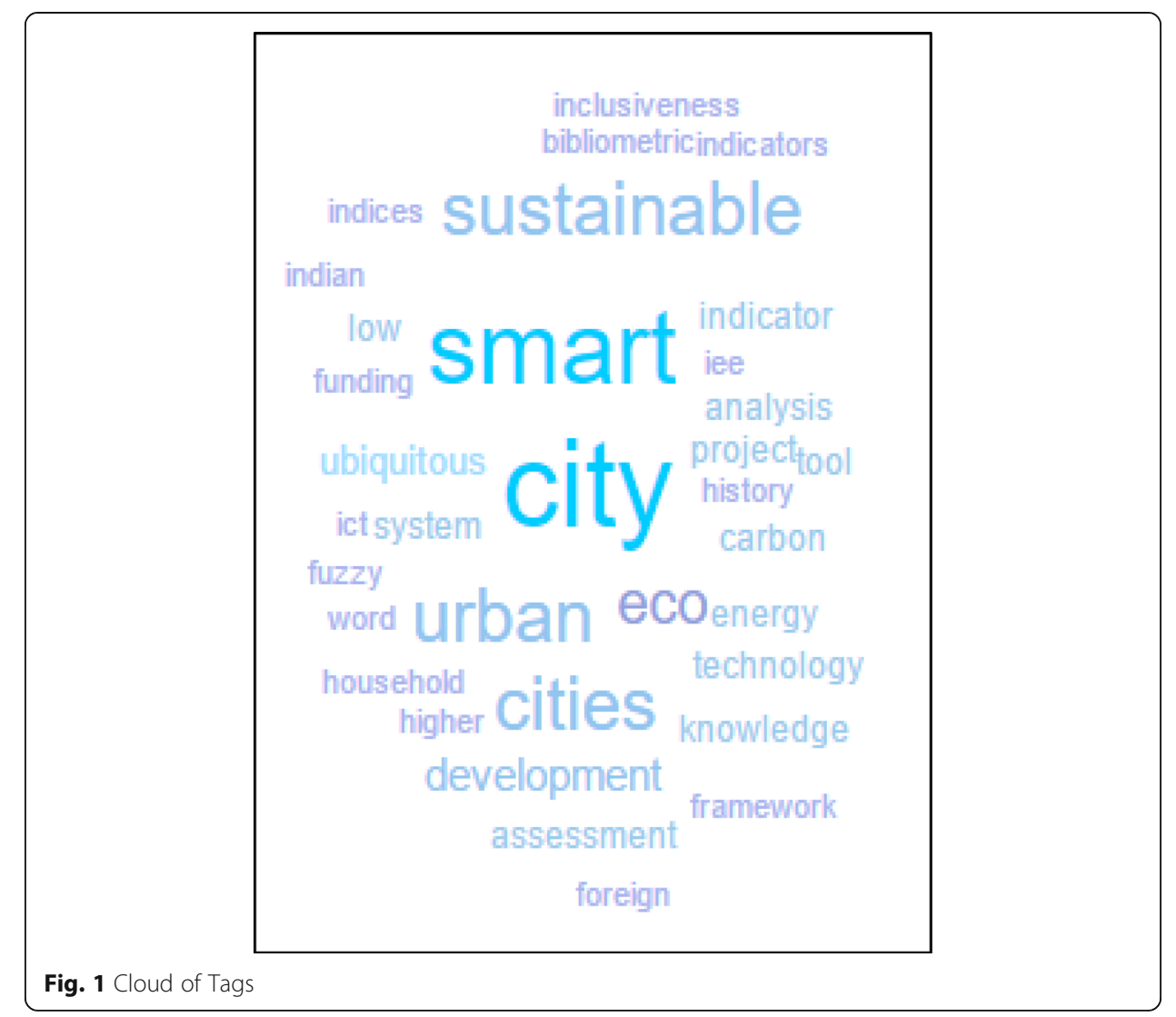

become popular only during the last 5 years. Figure 2 shows the timeline of the publications.

\section{Discussion and conclusion}

Environmental externalities mainly generated from population increase, rapid urbanization, high private motor vehicle dependency, deregulated industrialization, and mass livestock production have placed serious concerns for the future of our wellbeing, and even our existence in the long run. Realization of the fact that urgent measures must be taken to combat environmental externalities responsibly, effectively, and efficiently have resulted in the rediscovery of the need for more eco-friendly practices. Subsequently, during the last few decades, sustainability and sustainable development have become popular topics not only for scholars, particularly in the fields of environmental economics, technology and science, urban planning, development, and management, but also for urban policy makers and professional practitioners (Yigitcanlar et al. 2015). The emergence of these new concepts starting from early 1970s is an outcome

Table 4 Journals with high quantity of articles

\begin{tabular}{lll}
\hline Journals & Articles & Impact Factor 2015 \\
\hline Cities & 5 & 2.051 \\
Journal of Cleaner Production & 4 & 4.959 \\
Technological Forecasting \& Social Change & 3 & 2.678 \\
\hline
\end{tabular}




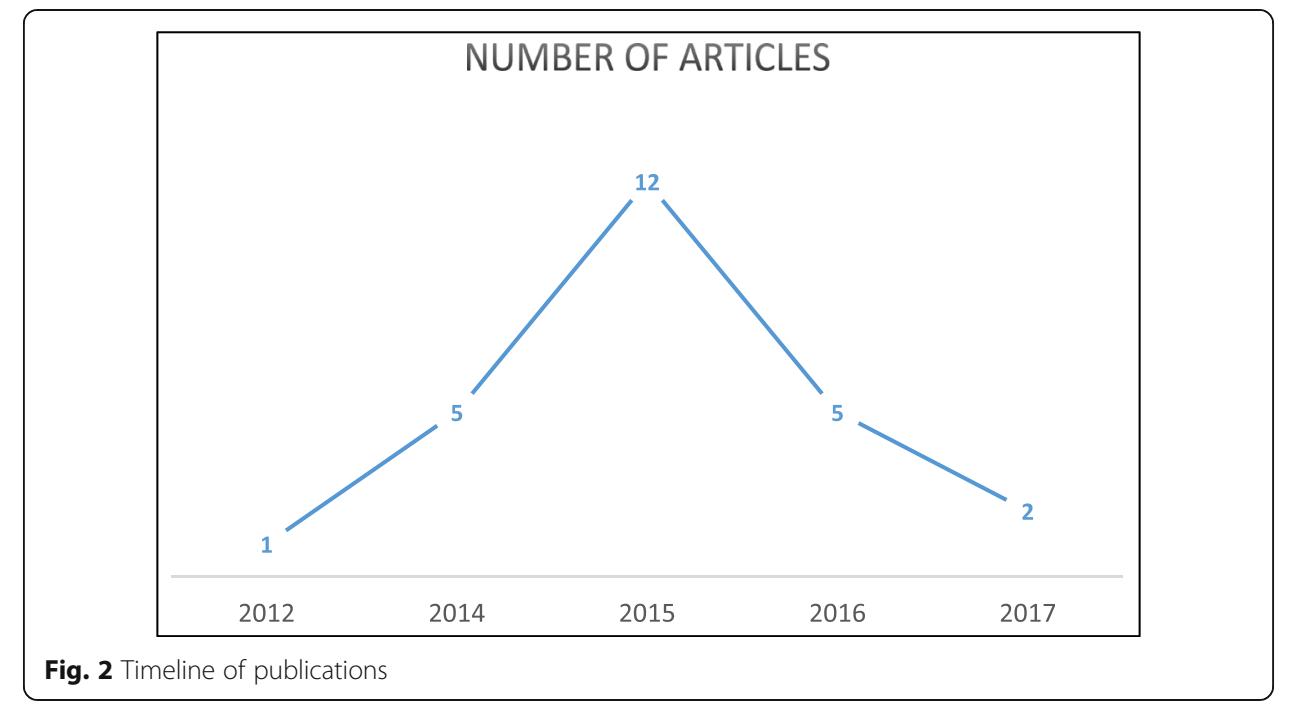

of the response to the growing concerns about the impacts of development practices on the state of the environment (Yigitcanlar and Kamruzzaman 2015).

Over the past decade smart urban technologies, as part of the smart and sustainable city agenda, have begun to blanket our cities with an aim of forming the backbone of a large and intelligent infrastructure. Along with this development, dissemination of the sustainability ideology has had a significant imprint on the planning and development of our cities. Today, the smart city concept is viewed as a vision, manifesto or promise aiming to constitute the twenty-first century's sustainable and ideal city form. In other words, smart city is an efficient, technologically advanced, green and socially inclusive city (Vanolo 2014). This is to say, smart city applications place a particular technology focus at the forefront of generating solutions for ecological, societal, economic, and management challenges (Yigitcanlar 2016).

This paper presented a theoretical basis on the concepts of smart city and sustainability through a thorough review of the literature. It generated some insight for to understand the relationship between the concepts of sustainable urban development and smart cities. The challenge of making cities more attractive to people brings the need for clarity in terms and concepts, unfortunately it is not the case with smart citie$\mathrm{s}$-although it is seen as a city that uses technology to generate environmental gains and sustainable outcomes (Baum et al. 2004). On the other hand, different than smart cities sustainable cities refer to the commitment to sustainable urban development. Moreover, despite their promise to deliver sustainable outcomes with the aid of advanced technology, smart cities are heavily criticised as being just a buzz phrase that has outlived their usefulness (Kunzmann 2014; Shelton et al. 2014; Yigitcanlar 2016). The provocation of this paper is, therefore, whether smart cities concept and practice can bring sustainability to our cities. The paper points out the need for prospective studies in answering this critical issue, where the review provided here could be a stepping stone for future studies. 


\section{Authors' contributions}

This paper represents a result of collegial teamwork. The authors designed the research jointly. The first two authors conducted the literature review and prepared the first draft of the manuscript. The last author finalised the manuscript. All authors read and approved the final manuscript.

\section{Competing interests}

The authors wish to acknowledge financial and/or in-kind contributions of the Federal University of Santa Catarina, and DGIST R\&D Program of the Ministry of Science, ICT \& Future Planning of Korea (14-IT) in supporting the research reported in this paper.

\section{Publisher's Note}

Springer Nature remains neutral with regard to jurisdictional claims in published maps and institutional affiliations.

\section{Author details}

${ }^{1}$ Engineering and Knowledge Management, Federal University of Santa Catarina, Campus Universitário, Trindade, Florianópolis, SC CEP 88040-900, Brazil. ${ }^{2}$ World Capital Institute, E. Garza Sada 2501 Sur, P.C. 64849, Monterrey, N.L, Mexico.

Received: 16 May 2017 Accepted: 22 July 2017

Published online: 04 August 2017

\section{References}

Ahvenniemi, H., Huovila, A., Pinto-Seppä, I., \& Airaksinen, M. (2017). What are the differences between sustainable and smart cities? Cities, 60, 234-245.

Andrade, J. B. S. O., Ribeiro, J. M. P., Fernandez, F., Bailey, C., Barbosa, S. B., \& da Silva Neiva, S. (2016). The adoption of strategies for sustainable cities: A comparative study between Newcastle and Florianópolis focused on urban mobility. Journal of Cleaner Production, 113, 681-694.

Angelidou, M. (2014). Smart city policies: A spatial approach. Cities, 41, S3-S11.

Angelidou, M. (2015). Smart cities: A conjuncture of four forces. Cities, 47, 95-106.

Baum, S., Van Gellecum, Y., \& Yigitcanlar, T. (2004). Wired communities in the city: Sydney, Australia. Geographical Research, 42(2), 175-192.

Bayulken, B., \& Huisingh, D. (2015). Are lessons from eco-towns helping planners make more effective progress in transforming cities into sustainable urban systems: A literature review (part 2 of 2). Journal of Cleaner Production, 109, 152-165.

Caragliu, A., Del Bo, C., \& Nijkamp, P. (2011). Smart cities in Europe. Journal of Urban Technology, 18(2), 65-82.

Carrillo, J., Yigitcanlar, T., Garcia, B., \& Lonnqvist, A. (2014). Knowledge and the city: Concepts, applications and trends of knowledge-based urban development. New York: Routledge.

Carvalho, L., \& Campos, J. B. (2013). Developing the PlanIT Valley: A view on the governance and societal embedding of u-eco city pilots. International Journal of Knowledge-Based Development, 4(2), 109-125.

Cocchia, A. (2014). Smart and digital city: A systematic literature review. In Smart city (pp. 13-43). Berlin: Springer.

Cohen, B., \& Amorós, J. E. (2014). Municipal demand-side policy tools and the strategic management of technology life cycles. Technovation, 34(12), 797-806.

Conventz, S., Thierstein, A., Wiedmann, F., \& Salama, A. M. (2015). When the Oryx takes off: Doha a new rising knowledge hub in the Gulf region? International Journal of Knowledge-Based Development, 6(1), 65-82.

Deakin, M., \& Al Waer, H. (Eds.). (2012). From intelligent to smart cities. New York: Routledge.

Dhingra, M., \& Chattopadhyay, S. (2016). Advancing smartness of traditional settlements-case analysis of Indian and Arab old cities. International Journal of Sustainable Built Environment, 5(2), 549-563.

Dizdaroglu, D., \& Yigitcanlar, T. (2014). A parcel-scale assessment tool to measure sustainability through urban ecosystem components: The MUSIX model. Ecological Indicators, 41(1), 115-130.

Dizdaroglu, D., \& Yigitcanlar, T. (2016). Integrating urban ecosystem sustainability assessment into policy-making: Insights from the gold Coast City. Journal of Environmental Planning and Management, 59(11), 1982-2006.

Edvardsson, l., Yigitcanlar, T., \& Pancholi, S. (2016). Knowledge cities research and practice under the microscope: A review of the literature. Knowledge Management Research and Practice, 14(4), 537-564.

Ferenhof, H. A., \& Fernandes, R. F. (2016). Desmistificando a revisão de literatura como base para redação científica: método SFF. Revista ACB, 21(3), 550-563.

Fu, Y., \& Zhang, X. (2017). Trajectory of urban sustainability concepts: A 35-year bibliometric analysis. Cities, 60, 113-123.

Goonetilleke, A., Yigitcanlar, T., Ayoko, G., \& Egodawatta, P. (2014). Sustainable urban water environment: Climate, pollution and adaptation. Cheltenham: Edward Elgar.

Götz, G., \& Schäffler, A. (2015). Conundrums in implementing a green economy in the Gauteng City-region. Current Opinion in Environmental Sustainability, 13, 79-87.

Gudes, O., Kendall, E., Yigitcanlar, T., Pathak, V., \& Baum, S. (2010). Rethinking health planning: a framework for organising information to underpin collaborative health planning. Health Information Management Journal, 39(2), 18-29.

Harrison, C., Eckman, B., Hamilton, R., Hartswick, P., Kalagnanam, J., Paraszczak, J., \& Williams, P. (2010). Foundations for smarter cities. IBM Journal of Research and Development, 54(4), 1-16.

Hiremath, R. B., Balachandra, P., Kumar, B., Bansode, S. S., \& Murali, J. (2013). Indicator-based urban sustainability: A review. Energy for Sustainable Development, 17(6), 555-563.

Hortz, T. (2016). The smart state test: A critical review of the smart state strategy 2005-2015's knowledge-based urban development. International Journal of Knowledge-Based Development, 7(1), 75-101. 
Hu, M. C., Wu, C. Y., \& Shih, T. (2015). Creating a new socio-technical regime in China: Evidence from the SinoSingapore Tianjin Eco-City. Futures, 70, 1-12.

Hu, M. C., Wadin, J. L., Lo, H. C., \& Huang, J. Y. (2016). Transformation toward an eco-city: Lessons from three Asian cities. Journal of Cleaner Production, 123, 77-87.

Jesson, J., Matheson, L., \& Lacey, F. M. (2011). Doing your literature review: Traditional and systematic techniques. London: Sage.

Jong, M., Joss, S., Schraven, D., Zhan, C., \& Weijnen, M. (2015). Sustainable-smart-resilient-low carbon-eco-knowledge cities; making sense of a multitude of concepts promoting sustainable urbanization. Journal of Cleaner Production, $109,25-38$.

Joss, S. (2015). Eco-cities and sustainable urbanism. In International encyclopedia of the Social \& Behavioral Sciences (pp. 829-837). New York: Elsevier.

Komninos, N. (2002). Intelligent cities: Innovation, knowledge systems, and digital spaces. New York: Taylor \& Francis.

Komninos, N. (2016). Smart environments and smart growth: Connecting innovation strategies and digital growth strategies. International Journal of Knowledge-Based Development, 7(3), 240-263.

Kondepudi, S. N. (2014). Smart sustainable cities analysis of definitions. The ITU-T focus Group for Smart Sustainable Cities, United Nations, Washington.

Kramers, A., Höjer, M., Lövehagen, N., \& Wangel, J. (2014). Smart sustainable cities-exploring ICT solutions for reduced energy use in cities. Environmental Modelling \& Software, 56, 52-62.

Kunzmann, K. R. (2014). Smart cities: A new paradigm of urban development. Crios, 4(1), 9-20.

Lara, A., Costa, E., Furlani, T., \& Yigitcanlar, T. (2016). Smartness that matters: Comprehensive and human-centred characterisation of smart cities. Journal of Open Innovation, 2(8), 1-13.

Lazaroiu, G. C., \& Roscia, M. (2012). Definition methodology for the smart cities model. Energy, 47(1), 326-332.

Lee, J. H., Hancock, M. G., \& Hu, M. C. (2014). Towards an effective framework for building smart cities: Lessons from Seoul and San Francisco. Technological Forecasting and Social Change, 89, 80-99.

Lee, S. H., Han, J. H., Leem, Y. T., \& Yigitcanlar, T. (2008). Towards Ubiquitous City: Concept, Planning, and Experiences. Igi Global, 2, 148-169.

Marsal-Llacuna, M. L., \& Segal, M. E. (2016). The Intelligenter method (I) for making "smarter" city projects and plans. Cities, 55, 127-138.

Marsal-Llacuna, M. L., Colomer-Llinàs, J., \& Meléndez-Frigola, J. (2015). Lessons in urban monitoring taken from sustainable and livable cities to better address the smart cities initiative. Technological Forecasting and Social Change, 90, 611-622.

Meadows, D. (1999). Indicators and information systems for sustainable development. In the Earthscan reader in sustainable cities (pp. 1-78). London: Earthscan.

Nam, T., \& Pardo, T. A. (2011). Conceptualizing smart city with dimensions of technology, people, and institutions. In Proceedings of the 12th annual international digital government research conference: Digital government innovation in challenging times (pp. 282-291). ACM.

Neirotti, P., De Marco, A., Cagliano, A. C., Mangano, G., \& Scorrano, F. (2014). Current trends in smart city initiatives: Some stylised facts. Cities, 38, 25-36.

Pancholi, S., Yigitcanlar, T., \& Guaralda, M. (2015). Public space design of knowledge and innovation spaces: Learnings from Kelvin grove Urban Village, Brisbane. Journal of Open Innovation, 1(1), 1-17.

Pietrosemoli, L., \& Monroy, C. R. (2013). The impact of sustainable construction and knowledge management on sustainability goals. A review of the Venezuelan renewable energy sector. Renewable and Sustainable Energy Reviews, 27, 683-691.

Rode, P., Burdett, R., \& Soares Gonçalves, J. C. (2011). Buildings: Investing in energy and resource efficiency. In Towards a green economy: Pathways to sustainable development and poverty eradication. United Nations environment Programme (pp. 331-373).

Roy, M. (2009). Planning for sustainable urbanisation in fast growing cities: Mitigation and adaptation issues addressed in Dhaka, Bangladesh. Habitat International, 33(3), 276-286.

Schaffers, H., Komninos, N., Pallot, M., Trousse, B., Nilsson, M., \& Oliveira, A. (2011). Smart cities and the future internet: Towards cooperation frameworks for open innovation. In The future internet assembly (pp. 431-446). Berlin: Springer.

Scheel, C., \& Rivera, A. (2013). Innovative cities: In search of their disruptive characteristics. International Journal of Knowledge-Based Development, 4(1), 79-101.

Shelton, T., Zook, M., \& Wiig, A. (2014). The 'actually existing smart city'. Cambridge Journal of Regions, Economy and Society, 8, 13-25.

Tan, S., Yang, J., Yan, J., Lee, C., Hashim, H., \& Chen, B. (2017). A holistic low carbon city indicator framework for sustainable development. Applied Energy, 185, 1919-1930.

Townsend, A. M. (2013). Smart cities: Big data, civic hackers, and the quest for a new utopia. New York: WW Norton \& Company.

Tsolakis, N., \& Anthopoulos, L. (2015). Eco-cities: An integrated system dynamics framework and a concise research taxonomy. Sustainable Cities and Society, 17, 1-14.

Vanolo, A. (2014). Smartmentality: The smart city as disciplinary strategy. Urban Studies, 51(5), 883-898.

WCED (World Commission on Environment and Development) (1987). Report of the world commission on environment and development: Our common future. United Nations. http://www.un-documents.net/our-commonfuture.pdf. Accessed 9 Feb 2017

Yigitcanlar, T. (2006). Australian local governments' practice and prospects with online planning. URISA Journal, 18(2), 7-17.

Yigitcanlar, T. (2015). Smart cities: an effective urban development and management model? Australian Planner, 52(1), 27-34

Yigitcanlar, T. (2016). Technology and the city: Systems, applications and implications. New York: Routledge.

Yigitcanlar, T., \& Baum, S. (2008). Benchmarking local e-government. In Electronic Government: Concepts, Methodologies, Tools, and Applications (pp. 371-378). IGI Global.

Yigitcanlar, T., \& Dizdaroglu, D. (2015). Ecological approaches in planning for sustainable cities: A review of the literature. Global Journal of Environmental Science and Management, 1(2), 71-94. 
Yigitcanlar, T., \& Kamruzzaman, M. (2014). Investigating the interplay between transport, land use and the environment: A review of the literature. International journal of Environmental Science and Technology, 11(8), 2121-2132.

Yigitcanlar, T., \& Kamruzzaman, M. (2015). Planning, development and management of sustainable cities: A commentary from the guest editors. Sustainability, 7(11), 14677-14688.

Yigitcanlar, T., \& Lee, S. H. (2014). Korean ubiquitous-eco-city: A smart-sustainable urban form or a branding hoax? Technological Forecasting and Social Change, 89, 100-114.

Yigitcanlar, T., \& Lönnqvist, A. (2013). Benchmarking knowledge-based urban development performance: Results from the international comparison of Helsinki. Cities, 31, 357-369.

Yigitcanlar, T., \& Teriman, S. (2015). Rethinking sustainable urban development: Towards an integrated planning and development process. International journal of Environmental Science and Technology, 12(1), 341-352.

Yigitcanlar, T., \& Velibeyoglu, K. (2008). Knowledge-based urban development: The local economic development path of Brisbane, Australia. Local Economy, 23(3), 195-207.

Yigitcanlar, T., Dodson, J., Gleeson, B., \& Sipe, N. (2007). Travel self-containment in master planned estates: analysis of recent Australian trends. Urban Policy and Research, 25(1), 129-149.

Yigitcanlar, T., Dur, D., \& Dizdaroglu, D. (2015). Towards prosperous sustainable cities: A multiscalar urban sustainability assessment approach. Habitat International, 45(1), 36-46.

Zhou, N., He, G., Williams, C., \& Fridley, D. (2015). Elite cities: A low-carbon eco-city evaluation tool for China. Ecological Indicators, 48, 448-456.

Submit your manuscript to a SpringerOpen ${ }^{\circ}$ journal and benefit from:

- Convenient online submission

- Rigorous peer review

- Open access: articles freely available online

- High visibility within the field

- Retaining the copyright to your article

Submit your next manuscript at $\gg$ springeropen.com 